\title{
THE IMPACT OF TECHNOLOGY READYNESS TOWARDS THE USAGE OF E-COMMERCE MEDIATED USING TAM BY MSME
}

\author{
Kusuma Iswahyuni ${ }^{1}$, Sanaji ${ }^{2}$ \\ \{kusumaiswahyuni@mhs.unesa.ac.id ${ }^{1}$, sanaji@unesa.ac.id $\left.{ }^{2}\right\}$ \\ ${ }^{1,2}$ State University of Surabaya, Indonesia
}

\begin{abstract}
The objective of study is to investigate the impact of technology readiness toward the usage of e-commerce with perceived ease of use and perceived usefulness as the intervening variable. The data collection technique used in this study is snowball sampling with 40 samples of respondents. Analytical technique used is PLS (Partial Least Square) method. The result of study showing that variable's technology readiness give no impact toward the perceived ease of use give impact toward variable's perceived usefulness, variable's perceived ease of use also give no impact toward the usage of ecommerce, while perceived usefulness have some impact to the usage of e-commerce.
\end{abstract}

Keywords: technology readiness, perceived ease of use, perceived usefulness, and the usage of e-commerce

\section{Introduction}

As the $4^{\text {th }}$ largest country in terms of population, Indonesia needs to stabilize the number of population and job vacancies in order to fulfill daily needs. Based on the data of Badan Pusat Statistik (Central Bureau of Statistic), in 2013, the number of job seekers reached up to $1,051,944$ and rose to $1,295,149$ in 2014 . Eventhough the number of job vacancies rises from 612,699 in 2013 to 816,505 in 2014, this number is not enough to fulfill the number of job seekers. Until 2015, the numbers of listed job vacancy is 833,555 while the number of listed job seeker reach up to $1,401,428$. This can be concluded that the number of people in Indonesia that remain unemployed is high.

Based on the data from BPS, to reduce the number of unemployment in Indonesia that keeps increasing each year, the government needs to establish cooperation with MSME (Micro, Small, and Medium Enterprises). The contribution of MSME towards GDP (Gross Domestic Product) able to employed $10.7 \%$ or roughly 12 million workers (CNN Indonesia Business news, 2016). The high number of employment needs to be balanced with the proses of marketing as well. Modern marketing mostly is using internet to carry out the process of selling using computer or known as online marketing.

According to Kotler \& Amstrong (2008:237), online marketing is a type of marketing that has the most rapid growth. Enterprises attempt to sell their product and service also build connection with the customers through internet. Kotler \& Amstrong (2008:252) also add, if online marketing keeps growing, it would be the proof that online marketing is a marketing 
method that is reliable to build relationship with customers, increase sells, share information about products and services, and deliver products and services effectively.

Quoting from beritajatim.com, it states that the growth of MSME in Sidoarjo is rapidly increasing. Based on the numbers and the growth of MSME in 2013, Sidoarjo is declared as 'Sidoarjo Kota UKM Indonesia' (Sidoarjo the city of MSME in Indonesia). Chambers of Commerce and Industry of Sidoarjo supports MSME on 18 sub-districts to sells their product online. The program of online business that is called as Kampung UKM Digital (village of digital MSME) is done together by Chambers of Commerce and Industry of Sidoarjo, Telkom, and Universities in Sidoarjo. One of the Kampung UKM Digital is Kampung UKM Digital Tanggulangin Goes Digital.

The continuation of the program Kampung UKM Digital that is not well maintained made online shop of Kampung UKM Digital member less attracting. Moreover, KKN-PPM program of UNESA in 2016, Gerai Kapersi, is not working well because of the consistency and commitment that is still needed to be improved. The owners of MSME still depend on Offline shop. Those explanation indicates e-commerce has great potential but found many problems during the process.

To use online marketing, several things need to be prepared. According to Rahayu \& Day (2015) supporting factor in online marketing is perceived benefit, technology readiness, owner innovativeness, owner IT experience, and owner IT ability. But according to Zhu et al (2006) technology readiness is the main factor to use e-commerce in developing country. According to Parasuraman (2000) "the technology-readiness construct refers to people's propensity to embrance and use new technologies for accomplishing goals in home life and at work".

One of the theories about the use of information and technology that is considered giving great impact and generally used to explain about individual acceptance towards the use of information and technology is TAM (Technology Acceptance Model). This theory introduced by Davis (1986) and developed into TRA (Theory of Reasoned Action) by Ajzen and Fisben (1980). Jogiyanto (2007:1) also stated, TAM emphasizes 2 main constructors into TRA. 2 main constructors are perceived usefulness and perceived ease of use. According to Jogiyanto (2007:115) perceived ease of use is giving influence to perceived usefulness.

The development of the use of TAM model is divided into 2 contexts that are TAM before the use of technology and TAM after the use of technology. The use of TAM before technology can be found on the research of Davis (1986) that states Attitude toward using as the effective response that directly influenced by the attitude of the subject on using new technology. The use of TAM after technology placed attitude on the usage that giving focus on the continuation of the usage or stop using technology.

\section{Research Method}

The research design on this research is using conclusive research design, because the main purpose of conclusive research design is testing specific hypothesis and testing specific relation (Malhotra 2009:89). In the words, the basis of this research is survey by collecting primer data through questionnaire. The population is MSME on tanggulangin, using snowball sampling as the sampling method. the number on sample that is used is 40 respondents. To simplify the research, the respondents are divided into 2 group, online respondent and offline respondent. On the offline respondents, the researcher met the respondents directly. While on 
the online respondent, the respondents are requested to answer online questionnaire to simplify data collecting.

Data collection method is using questionnaire that is given directly to the respondents. The question type that is used on the questionnaire is closed-ended question, a type of question that allows the respondent to choose the answer according to the given answer. Scaling method that is used is likert scale. Before the questionnaire shared, it was tested previously for the validity and reliability using SPSS. The collected data from questionnaire then processed using PLS (Partial Least Square) method.

\section{Result and Discussion}

Respondent characteristic that become the subject of research is enterpreneur or online shop administrator from MSME that are using e-commerce. Respondent has customers that bought their product online. TAM construct that is used for this research is perceived ease of use, perceived usefulness, and online marketing (e-commerce) and media that is used is whatsapp.

Hypothesis test that is done in this research is using Structural Equation Modeling with the support of software SmartPLS ver 3.0. PLS is a powerful analysis method because it is not assuming data with scale measurement and small sample (Wold in Ghozali, 2013:4). PLS-SEM analysis is done by valuing outer model and inner model. The indicator can be assessed as valid when value of correlation reaches more than 0.70 . Eventhough it is not reach 0.70 , for the early stage research, loading value between 0.50 up to 0.60 can be considered sufficient (Chin in Ghozali, 2014: 39).

Four of the dimensions are relatively independent with every one of them showing the will of someone to accept technology. Optimism and innovativeness dimensions are the driver of the technology readiness, while discomfort and insecurity are the inhibitor. Parasuraman \& Colby argue that user segment with technolofy readiness profile can be different and varied significantly in terms of internet behavior. That is why technology readiness cannot be ignored in assessing user of technology-based services. Based on the previous explanation, in this research optimism and innovativeness will be used to measure technology readiness toward the user of e-commerce (Parasuraman \& Colby,2001). 


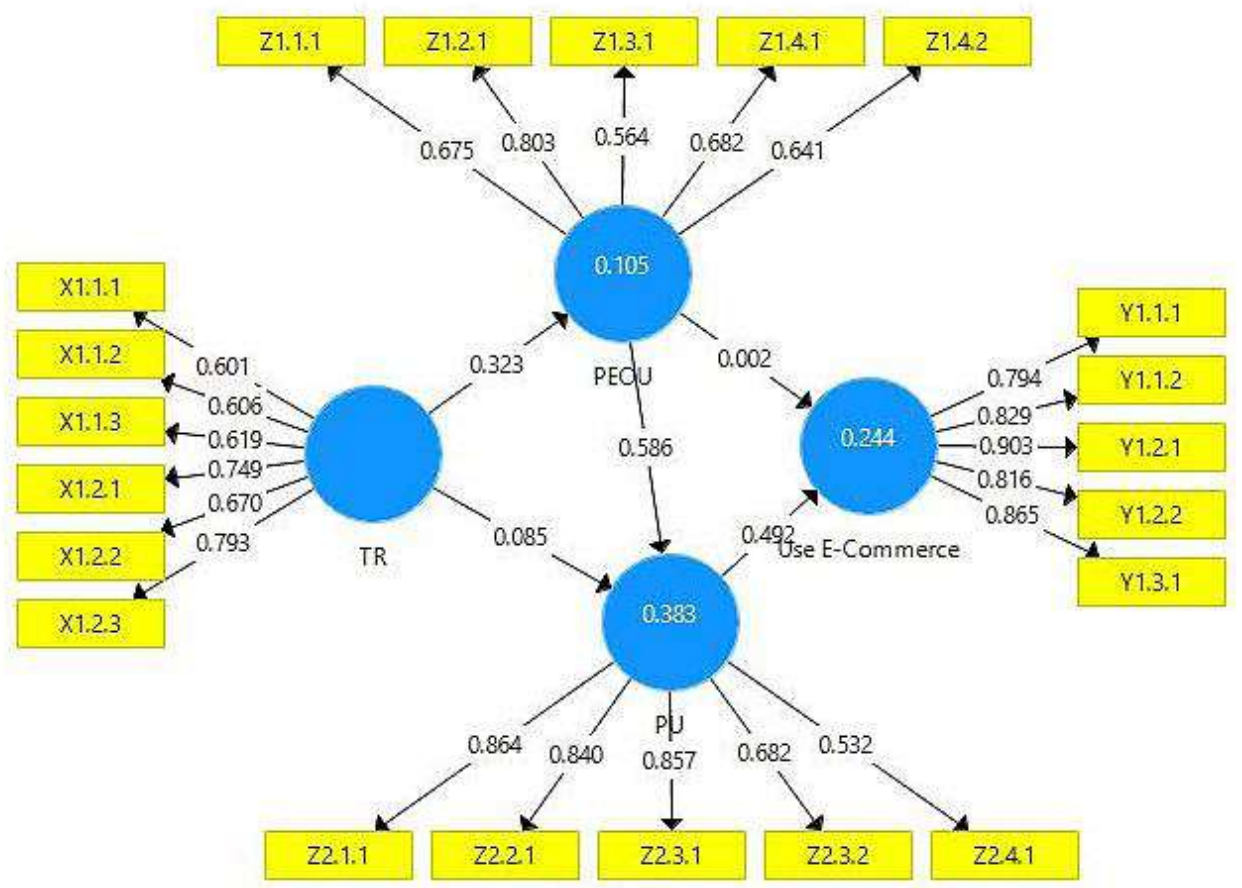

Figure 1. Measurement Model Test

According to figure 1 , it can be marked that all outer loading is above 0.50 . based on that value, it can be concluded that variables above are having good convergent validity. Technology readiness variable with 4 dimensions that are optimism, innovativeness, discomfort dan insecurity has one of the dimensions with outer loading below 0.5. The following explaination is:

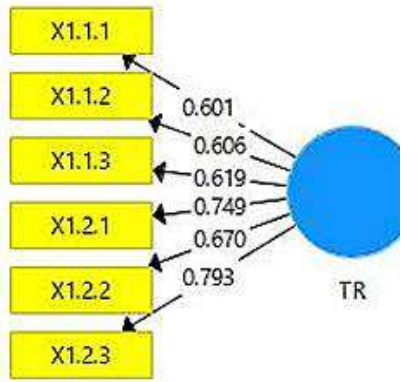

Figure 2. Measurement Model Test Variable Technology Readiness Optimism \& Innovativeness Dimensions

Figure 2 is showing that outer loading from each item of technology readiness for optimism \& innovativeness dimensions is above 0.50 . 


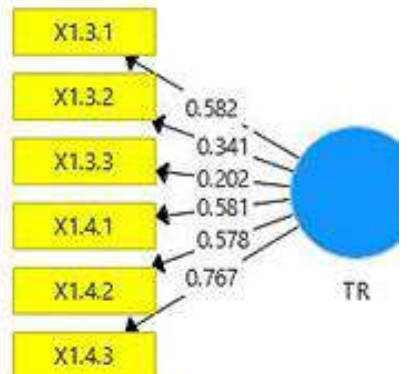

Figure 3. Measurement Model Test Variable Technology Readiness Discomfort \& Insecurity Dimensions

Figure 3 is showing that outer loading from discomfort with just X1.3.1 that has value more than 0.50 , while items X.1.3.2 \& X.1.3.3 have value less than 0.50. For each item of insecurity dimension has value above 0.50 .

Four of the dimensions are relatively independent with every one of them showing the will of someone to accept technology. Optimism and innovativeness dimensions are the driver of the technology readiness, while discomfort and insecurity are the inhibitor. Parasuraman \& Colby argue that user segment with technolofy readiness profile can be different and varied significantly in terms of internet behavior. That is why technology readiness cannot be ignored in assessing user of technology-based services. Based on the previous explanation, in this research optimism and innovativeness will be used to measure technology readiness toward the user of e-commerce (Parasuraman \& Colby,2001).

Next is composite reliability and croncabch's alpha to determine the reliability of good and strong if the value is $>0.70$.

Table 1. Composite Reliability.

\begin{tabular}{cc}
\hline Variable & Composite Reliability \\
\hline Technology readiness & 0,834 \\
Perceived ease of use & 0,807 \\
Perceived usefulness & 0,873 \\
Use of E-Commerce & 0,924 \\
\hline
\end{tabular}

Source : Output PLS 3.0

According to table 1 , the value of composite reliability for each of variables are above 0.70 . it can be concluded that this variable model fulfills the composite reliability or having good reliability. 
Table 2. Croncabch's Alpha

\begin{tabular}{cc}
\hline Variable & Croncabch's Alpha \\
\hline Technology readiness & 0,781 \\
Perceived ease of use & 0,704 \\
Perceived usefulness & 0,816 \\
Use of E-Commerce & 0,901 \\
\hline
\end{tabular}

Source : Output PLS 3.0

The table 2 shown that the value of Croncabch's alpha for all of the constructs are above 0.70 . This is showing that this variable model fulfills the Croncabch's alpha or having strong reliability.

Inner model can be calculated by calculating the relation between construct and the value of significance on the table path coeffients as shown on table 3 below. the test between variable can be assessed as "giving impact" if t-statistics > t-table 5\% $(1,96)$.

Table 3. Path Coeffecients Result

\begin{tabular}{ccccc}
\hline Hubungan Antar Variabel & $\begin{array}{c}\text { Original } \\
\text { Sample }\end{array}$ & $\mathrm{T}_{\text {Statistics }}$ & Information \\
\hline Technology readiness $\rightarrow$ Perceived Ease of Use & 0,323 & 1,299 & $\mathrm{H}_{1}$ rejected \\
Technology readiness $\rightarrow \quad$ Perceived Usefulness & 0,085 & 0,444 & $\mathrm{H}_{2}$ rejected \\
Perceived Ease of Use $\rightarrow \quad$ Perceived Usefulness & 0,586 & 3,908 & $\mathrm{H}_{3}$ accepted \\
Perceived Ease of Use $\rightarrow \quad$ Use of E-Commerce & 0,002 & 0,009 & $\mathrm{H}_{4}$ rejected \\
Perceived Usefulness $\rightarrow \quad$ Use of E-Commerce & 0,492 & 2,468 & $\mathrm{H}_{5}$ accepted \\
\hline
\end{tabular}

Source : Output PLS 3.0

According to table 3, the result can be explained as following:

First hypothesis that states technology readiness gives positive impact toward the perceived ease of use is rejected with $t_{\text {statistics }}$ value 1,299 . The coefficient parameter 0,323 has meaning that there is positive impact of technology readiness toward perceived ease of use. Coefficient parameter that has positive value can be be implemented as the higher technology readiness would make perceived ease of use higher as well. This result supports the research conducted by Walczuch et al (2007) that states technology readiness is not giving impact toward perceived ease of use because of the respondent is less optimistic to learn using new technology did not believe that it would makes the technology easier to use.

The second hypothesis that states technology readiness gives positive impact toward the perceived usefulness is rejected with $t_{\text {statistics }}$ value 0,444 . The coefficient parameter 0,085 has meaning that there is positive impact of technology readiness toward perceived usefulness. Coefficient parameter that has positive value can be be implemented as the higher technology readiness would make perceived usefulness higher as well. This result supports the research conducted by Walczuch et al (2007) that states technology readiness is not giving impact toward perceived usefulness. This could be happened because the application (online shop) that is used is unusual to be used daily and creates a thought that this application (online shop) is not giving benefits.

The third hypothesis that states perceived ease of use gives positive impact toward the perceived usefulness is accepted with $t_{\text {statistics }}$ value 3,908 . The coefficient parameter 0,586 has meaning that there is positive impact of perceived ease of use toward perceived usefulness. Coefficient parameter that has positive value can be be implemented as the higher 
perceived ease of use would make perceived usefulness higher as well. This can be concluded that MSME, that is chosen to the respondent in this research, felt that using online marketing is easy and the use of online shop would support them increase the customers and income. This result supports the resultof the research conducted by Davis (1986), Davis (1989), Davis (1993) and Walzcuch et al (2007).

The fouth hypothesis that states perceived ease of use gives positive impact toward the use of e-commerce is rejected with $t_{\text {statistics }}$ value 0,009 . The coefficient parameter 0,002 has meaning that there is positive impact of perceived ease of use toward the use of e-commerce. Coefficient parameter that has positive value can be be implemented as the higher perceived ease of use would make the use of e-commerce higher as well. The research done by Dewi \& Warmika (2016) and Fayad \& Paper (2015) who confirm that perceived ease of use gives impact toward the use of e-commerce has different result with this research that confirms perceived ease of use is not giving impact on the use of e-commerce.

The fifth hypothesis that states perceived usefulness gives positive impact toward the use of e-commerce is accepted with $t_{\text {statistics }}$ value 2,468 . The coefficient parameter 0,492 has meaning that there is positive impact of perceived usefulness toward the use of e-commerce. Coefficient parameter that has positive value can be be implemented as the higher perceived usefulness would make the use of e-commerce higher as well. When the use of online marketing is high, the communication and transaction with customers using online is high as well. Based on that result, it can be concluded that perceived usefulness is giving great impact toward the us of e-commerce (online marketing) on MSME. According to the previous research, this result supports the research of Dewi \& Warmika (2016) and Fayad \& Paper (2015).

\section{References}

Agarwal, R., \& Karahanna, E. (2000). Cognitive Absorption And Beliefs About Information Technology UsagE, 24(4), 665-694.

Andi.2002.Apa \& Bagaimana E-Commerce.Semarang.Penerbit ANDI Yogyakarta.

Davis, F. (1986). A Technology Acceptance Model For Empirically Testing New End-User Information Systems: Theory And Results. PhDThesis - Massachussetts Institute of Technology. https://doi.org/10.1016/S0378-7206(01)00143-4

Davis, F. D. (1989). Perceived Usefulness, Perceived Ease Of Use, And User Acceptance. MIS Quarterly, 13(3), 319-339. https://doi.org/10.2307/249008

Davis, F. D. (1993). User Acceptance of Information Technology: System Characteristics, User Perceptions and Behavioral Impacts. International Journal of ManMachine Studies. https://doi.org/10.1006/imms.1993.1022

Dewi, N. M. A. P., \& Warmika, I. G. K. (2016). Peran Persepsi Kemudahan Penggunan, Persepsi Manfaat Dan Perspsi Resiko Terhadap Niat Menggunakan Mobile Commerce Di Kota Denpasar. E-Jurnal Manajemen Unud, 5(4), 2606-2636.

Fayad, Rima \& David Paper.(2015).The Technology Acceptance Model E-Commerce Extension: A Conceptual Framework. doi: 10.1016/S2212-5671(15)00922-3

Ferdinand, Agugusty.2014.Metode Pnelitian Manajemen Pedoman Penelitian untuk Skrips, Tesis dan Disertasi Ilmu Manajemen.Semarang:Universitas Diponegoro

Ferdinand, Augusty. 2006. Merode Penelitian Manajemen Pedoman Penelitian untuk Skrips, Tesis dan Disertasi Ilmu Manajemen.Semarang: Universitas Diponegoro.

Ghozali, Imam.2014.Structural Equation Modeling Metode Alternatif Dengan Partial Least Square (PLS) Edisi 4. Badan Universitas Diponegoro. Semarang. 
Ghozali, Imam. 2013. Aplikasi Analisis Multivariate dengan Program IBM SPSS 21, Update PLS Regresi. Cetakan ke-7. Badan Universitas Diponegoro. Semarang

Ghazali, Imam. (2011) Structural Equation Modelling: Metode alternatif dengan PLS. Edisi Ketiga. Semarang: Badan Penerbit UNiversitas Diponegoro.

Hermawan, Agus.2012.Komunikasi Pemasaran.Jakarta-Erlangga

Kotler, Phillip.2004.Dasar-dasar Pemasaran Jilid 1.Penerbit Erlangga.Jakarta.

Kotler, Phillip.2005.Dasar-dasar Pemasaran Jilid 2.Penerbit Erlangga.Jakarta.

Kotler, Phillip \& Gary Amstrong.2004.Dasar-dasar Pemasaran Jilid 1.Penerbit Erlangga.Jakarta.

Kotler, Philip \& Gary Amstrong.2008.Prinsip-Prinsip Pemasaran edisi ke-12.Penerbit Erlangga.

Liljander,V., Gillberg, F., Gummerus, J., \& van Riel, A. (2006).Technology Readiness And The Evaluation And Adoption Of Self-Service Technologies. Journal of Retailing and Consumer Services, 13, 177-191.

Ling, L.M. dan Moi, C.M. (2007),"Professional Students' Technology Readiness, Prior Computing Experience and Acceptance of An E-learning System" Malaysian Accounting Review, 6 (1), 85-99.

Liu,Shin-Ping, Dennis Tucker, Chng E. Koh \& Leon Kappelman.2003.Standard User Interface in E-Commerce Sites.http://www.emeraldinsight.com/.doi 10.1108/02635570310497648

Malhotra, Naresh K. 2009. Riset Pemasaran Pendekatan Terapan. Edisi Keempat. Jilid 1. Terjemahan oleh Soleh Rusyadi Maryam. 2005. Jakarta: PT. Indeks Kelompok Gramedia.

Pradana, mahir.(2015).Klasifikasi Jenis-Jenis Bisnis E-Commerce di Indonesia.Jurnal Neo-bis. Volume 9, No. 2, Des 2015

Prasetya, Filo Novandi \& Idris Gautama So.2014.Pengaruh E-Marketing dan E-CRM Terhadap E-Loyalty Website Usaha Komunikasi Pemasaran.Binus Business Review.Vol.5 No.1.8-17

Prins,J.E.J, P.M.A. Ribbers, H.C.A. van Tilborg, A.F.L. Veth and J.G.L. van deer Wees.2002.Trust in Electronic Commerce: The Role of Trust From A Legal, an Organisational and a Technical Point Of View.(online-book).ISBN:90411184549789041118455

Parasuraman, A. (2000).Technology readiness index (TRI): A multiple-item scale to measure readiness to embrace new technologies. Journal of Service Research, 2, 307-320

A.Parasuraman \& Charles L. Colby.2001.Techno-ready Marketing "How and Why Your Customers Adopt Technology”. (online-book).Simon\&Schuster

Purwohandoko, Sanaji dan Ali Mustofa.(2015).The Successful Implementation of E-Budgeting In Public University: A Study at Individual Level.Journal of Advances in Information Technology Vol. 6, No. 3

Rahayu, R., \& Day, J. (2015). Determinant Factors of E-commerce Adoption by SMEs in Developing Country: Evidence from Indonesia. Procedia - Social and Behavioral Sciences 195 ( 2015 ) $142-150$

Rogers, E.M. (1995).Diffusion of Innovation.New York: The Free Press

Sarwono, Jonathan. 2007. Pintar Menulis Karya Ilmiah-Kunci Sukses dalam Menulis Ilmiah. Yogyakarta: Andi

Schradi, B. (2009): Online Marketing Internet Lexikon [online] Available from: http://www.symweb.de/glossar/online-marketing__169.htm 
Sekaran, Uma. 2003. Path Analisis dengan SPSS: Teori, Aplikasi, Prosedur, Analisis untuk Riset Skripsi, Tesis dan Disertasi. Jakarta: PT Gramedia

Sher, P. J., Lin, C., \& Sher, P. J. (2007). Integrating Technology Readiness into Technology Acceptance: The TRAM Model, (June 2015). https://doi.org/10.1002/mar.20177

Smith, PR \& Dave Chaffey.2001.Emarketing Excellence.Routledge.(onlinebook).ISBN;1136003371,9781136003370

Strauss, Judy, Adel El Ansary \& Raymond Frost.2006.E-Marketing.Published by Prentice Hall-USA

Sugiarto, M., Soeprapto, A., \& Dewanti, I. S. (2015). Technology Readiness Dan Model Penerimaan Teknologi Informasi Mahasiswa, 217-226.

Sugiyono. 2014. Metode Penelitian Kuantitatif, Kualitatif, dan R\&D. Edisi 20 Penerbit ALFABETA. Bandung.

Suryani, Tatik.2013.Perilaku Konsumen di Era Internet.Yogyakarta.Graha Ilmu

Szajna, B. (1996). Empirical evaluation of the revised technology acceptance model.Management Science, 42, 85-92.

Tambunan, Tulus. (2002). Usaha Kecil dan Menengah di Indonesia: Beberapa Isu Penting. Jakarta: Salemba Empat.

Tim Penyusunan. 2014. Pedoman Penulisan Skripsi Universitas Negeri Surabaya. Surabaya : UNESA Press

Turban,E.2005.Decision Support Systems and Intelligent Systems Edisi Bahasa Indonesia Jilid 1.Andi, Yogyakarta

Venkatesh, V., \& Davis. (2000). A Theoretical Extension of the Technology Acceptance Model: Four Longitudinal Field Studies. Management Science, 46(2), 186-204. https://doi.org/10.1287/mnsc.46.2.186.11926

Venkatesh, V., \& Davis, F. D. (1996). A model of the antecedents of perceived ease of use: Development and test A Model of the Antecedents of Perceived Ease of Use: Development and Test* Model of Antecedents of Perceived Ease of Use. Summer, 27(3). https://doi.org/10.1111/j.1540-5915.1996.tb00860.x

Venkatesh, V., Morris, M. G., Davis, G. B., \& Davis, F. D. (2003). User acceptance of information technology: Towards a unified view. MIS Quarterly, 27, 425-478.

Walczuch, R., Lemmink, J., \& Streukens, S. (2007). The Effect of Service Employees' Technology Readiness on Technology Acceptance. Information \& Management, 44,206-215.

Wixom, Barbara H. \& Peter A. Todd.(2005).A Theorical Integration of User Satisfaction and Technology Acceptance. Information Systems Research Vol.16 No.1,March 2005,pp.85-102

Woodroof, J. B., \& Kasper, G. M. (1998). A conceptual development of process and outcome user satisfaction. Information Resources Management Journal, 11, 37-43.

Zhu, K., Kraemer, K.L. and Xu, S. (2006), "The process of innovation assimilation by firms in different countries: a technology diffusion perspective on e-business", Management Science, Vol. 52 No. 10, pp. 1557-1576

Zolait, Ali Hussein Saleh, Minna Mattila \& Ainin Sulaiman.2008.The Effect of User's Informational-Based Readiness on Innovation Acceptance.http://dx.doi.org/10.1108/02652320910928236 